\title{
PUTTING USER IN CONTEXT: A PARTICIPATORY DESIGN APPROACH USING A SIMULATED BEACH ENVIRONMENT - CORRIGENDUM
}

\author{
B. Khayamian Esfahani $\bowtie$ \\ University of East London, United Kingdom \\ $\bigotimes$ bkhayamian@uel.ac.uk
}

doi: https://doi.org/10.1017/dsd.2020.331. Published by Cambridge University Press, 11 June 2020.

The author's affiliation was published incorrectly in the aforementioned article. The correct affiliation is: University of East London, United Kingdom.

The author apologises for this error.

\section{Reference}

Khayamian Esfahani, B. (2020), "Putting User in Context: A Participatory Design Approach using a Simulated Beach Environment," in Proceedings of the Design Society: DESIGN Conference, Cambridge University Press, Vol. 1, pp. 1941-1948. https://doi.org/10.1017/dsd.2020.331 